811.163.41'374"1818“

811.163.41'373

https://doi.org/10.18485/mks_srpska_slavistika.2018.2.ch33

Зоја С. КАРАНОВИЋ ${ }^{*}$

Универзитет у Новом Саду

Филозофски факултет

\title{
ОБРЕДНА ЛЕКСИКА И ОБРЕДИ У РЈЕЧНИКУ (1818) ВУКА СТЕФАНОВИЋА КАРАЏИЋА
}

\begin{abstract}
Предмет овог рада је обредна лексика, односно номинација обредних поступака, те дескрипција обредно-обичајне праксе Караџићевог времена која је, ако је судити по обиму вокабулара и разноликости чланка које нуди Рјечник (1818), посебно занимала Вука Караџића. То се очитује у примарној лексици и, посебно, у описима значења христијанизованих празника из календарског циклуса (Аранђел, Варин дан, материще, оии, Божић, Бадњи дан, Богојављеније, Крстов дан, Лазарева субота, Васкресеније, Бурђев дан, Бурђии, Спасов дан, Тројице, Тројичин дан, Ивањдан, Митров дан...), примарно везаних за култ плодности, као и у иницијацијским елементима које ти обреди садрже. Осим тога, Рјечник је богат извор обредне лексике и изведених речи, те описа веровања, поступака, учесника, реквизита и вербализација који су поменуте празнике пратили - стихова, прича, фразеологије (бадњак, варича, букара, додоле, дружичало, завјетина, завјетовати се, коледа, крсно име, крстоноше, краљище, лазарице, лазити, милање, мирбожење, напијати, печеница, положајник, чесница и сл.). Богатство информација, као и лексике са симболичким значењем у стихованим формама и прозним облицима, налази се у Рјечнику и у опису обреда прелаза - рођење (бабине, једномјесечићи, спати, иуn), венчање (добјеглица, молитвена чаша, женидба, златоје, језичан, јенђебула, конђа, отмица, свадбарина, сват, чауш) и смрт (задушнице, даћа, нарикача). Ово је само део лексике која се налази у Рјечнику (1818), којим се Вук Караџић уврстио у пионире српске фолклористике и етнографије. Истраживање се врши с циљем да се утврди опсег и природа лексема које припадају наведеној тематској скупини, што би био један од индикатора релевантности обредно-обичајне праксе у духовној култури Срба, али и шире, у другим словенским заједницама, у којима је евидентирана аналогна обредно-обичајна пракса.

Кључне речи: Вук Караџић, Рјечник 1818, обредна лексика, обреди, српска култура, словенске културе.
\end{abstract}

Вук Ст. Караџић се, потакнут Копитарем, Гримом, Мушицким, ${ }^{1}$ још на почетку свог рада заинтересовао за народну културу и, у њеним оквирма, за обредно-обичајну праксу везану за кризне тренутке у човековом животу, календарске промене у

\footnotetext{
zoja@ff.uns.ac.rs

${ }^{1}$ О томе види: Љ. Стојановић (1924: 110-113; 125-140; 162-173); М. Филиповић (1972: 520-522); М. Радовановић (1973: 70-71).
} 
природи ${ }^{2}$ и аграрне празнике који се на њих односе, те одговарајућу лексику, ${ }^{3}$ што се може пратити већ у његовим раним песмарицама. А своју прву праву материјализацију ово Вуково занимање задобило у Рјечнику (1818), којим се он уврстио не само у осниваче српске лексикографије (в. Ивић 1966: 34-35) већ и етнографије и етнологије (в. Филиповић 1972: 514-515). ${ }^{4}$

У Пјеснарищи (1814) Караџић доноси две сватовске песме (бр. 85 и 86), чије извођење упућује на обредни контекст и аналогну лексику (прва је певана „кад полазе сватови с девойком”, друга: „код младоженьине куће, кад сватови долазе са девойком". И Пјеснарица (1815)5 садржи циклус сватовских песама (бр. 54-68), где су такође подаци о времену извођења и учесницима припадајућих обреда. А уз песме бр. 58 и бр. 60. бележе се и ситуације у којима су певане. Прва: „На вратима затворенымъ” по Бачкој где је „обычай да само младоженю пусте къ дъвойцы, пакъ онда препрече врата, те остали сватови мораю плаћати, кои е радъ да види дъвойку пріе него е изведу” и додаје да по Србији само девера пусте, али да и он мора платити; ,а младоженя ту не сміе ни приступити", што је опис код Срба и данас распрострањеног обичаја „на вратима” девојачким, и некада је био у вези с табуом виђења и показивања, те с опасностима поступног превођења у нову заједницу. Уз песму бр. 60, пак, стоји објашњење да се певала: „Кад’ хоће братъ да изведе дъвойку” и: „Свуда је кодъ Србаля обычай да братъ (или братучедъ, ако не има брата) изведе дБвойку и да преда деверу" (што се понегде ради и данас) и такође је било повезано с превођењем у нову заједницу. Караџић је, дакле, од почетка истицао важност обреда за познавање културе народа преко поезије и све је то у ширем захвату инкорпорирао у Рјечник. А већ тада је описивао и њихове варијетете у различитим крајевима, чиме скреће пажњу на разлике у испољавању одређених сегмената ритуала у појединим областимма и тако постаје претеча картографирања етнографског и фолклорног материјала, популарног у 20. веку (в. Толстой 1995: 20).

Више података о учесницима, њиховим функцијама у појединим фазама обреда, с дескрипцијом поступака и фокусирањем на радњу (у игри хватања сламке), он даје уз песму под бр. 97, која је певана: „Кад се ньива дожанъ”, у оквиру постжетвеног весеља, које је у обреду љубљења имало обележја ритуалне смеховности - пошто правило игре налаже да се љуби онај чију сламку саиграч ухвати, без обзира на старосну доб: „Да гледамо ко ће коме, / У срећи пасти. / Коме старо, коме

${ }^{2}$ Караџић их је називао: „Обичаји о најзнатнијим људским догађајима” и „Обичаји о различнијем празницима” (Караџић 1867, према изд. 1972: 217, 153). А. А. Плотникова их вазује за, како каже: „народный календарь” и назива их: „,ельскоехозяйственая обрядность” и „семейственая обрядность” (Плотникова 2004: 9).

${ }^{3}$ Обредна лексика односи се на означавање утврђених радњи и поступака у којима учествују одређена лица, реквизити, односно предмети, које се везују за утврђено време и место, у међусобном прожимању, који се у култури именују на специфичан начин и имају симболички, шифровани смисао (в. Толстой 1995a: 63). Та лексика чини део система датог језика и културе у којој се обред формирао.

${ }^{4}$ О овој димензији Вуковог дела писали су Ј. Копитар, Ј. Грим, Срезњевски (1846); Ђ. Даничић (1847), Шафарик (1865) (Филиповић 1972; 513, 539-540, 543; Радовановић 1973: 79); његове етнографске квалитете истицали су Љ. Стојановић и Т. Вукановић (према Радовановић 1973: 74-79). Прво издање Рјечника иначе има око 27.000 речи, друго, са ширег језичког подручја, 47.000. Отприлике је такав и размер обредне лексике у њима.

${ }^{5}$ Штампана, како аутор каже, на херцеговачком и сремачком дијалекту (Караџић 1818: IX-X). O томе и: Филиповић 1972: 536; Радовановић 1973: 70-71. 
младо / Ком’ што срећа да...” - везане за аграрне култове, чиме већ тада наговештава важност овог сегмента културе.

Збирка садржи и изузетно вредну руковет краљичких песама (бр. 69-92), ${ }^{6}$ с детаљним описом обреда који им претходи. Говори се о времену упражњавања, актерима, подели улога, одећи, опходу, начину извођења, игри, реквизитима, његовој географској распрострањености, чиме се истиче важност повезаности акционалне и вербалне стране обреда. И све то у нешто измењеном облику преноси у Рјечник, уз одредницу краљиие.

У Додатку је неколико славских песама (в. Филиповић 1972: 525-527, 536), без коментара, али које садржином упућују на ритуално извођење, као и руковет жетелачких стихова (бр. 93-101) и једна прелска песма (бр. 99) (в. Филиповић (1972: 521), чиме се шири дијапазон обреда у које је Караџић од почетка имао увида.

Ова збирка опскрбљена је и Толкованијем речи, с неколико лексема из поменутог тематског поља: енга (из песме бр. 56); лељо (у песми бр. 69), молитвена чаша (у јуначкој песми бр. 10) и ручни девер (у белешци уз песму бр. 58, бр. 60 у песми бро 61, бр 64, в. Филиповић 1972; 522). И ове речи, антиципирајући његов будући рад, с мањим или већим изменама и алфабетским померањима, ушле су у Рјечник - само што се у Рјечнику, због природе посла, полази од лексеме ка тумачењу њеног значења.

Рјечником (1818) Караџић је иначе представио лексички фонд српског језика (у различитим говорима), ${ }^{7}$ њему савременог тренутка, што у предговору и каже: „ријечи што су овде скупљене [...] све у народу познате и овако [...] се изговарају као што су овђе записане” (Караџић 1818: VII), ${ }^{8}$ инсистирајући на верном записивању савременог језичког материјала. Уз то је настојао да представи и опише и „ђекоје народне обичаје"9 (Караџић 1818: VIII), као и да их детаљно објасни, о чему каже: „у Рјечнику треба да се истолкује и опише што се боље може све што народ о ријечи једној зна и приповиједа” (Караџић 1818: VIII). Или: „У Рњчнику ће Србском бити описани скоро сви обычаи Србски” (Добрашиновић 1988: 122), пише он Мушицком, 1816 (в. и Филиповић 1972: 520; Радовановић 1973: 70). Тиме ова књига улази у окружење речника „новога” типа, у којима се користио „емпиријски етнолингвистички приступ” (в. Плотникова 2000: 11, 21-31). Фокусирање на однос речи и културе, односно језика и културе савременог доба, до краја ће остати Вукова прео-

${ }^{6}$ За краљичке песме Караџић се у Предговору захваљује Максиму Ранковићу, од кога их је и добио (IX, према изд. 1965: 141).

${ }^{7}$ Рјечник је заснован на дијалекатској основи и обухвата штокавски језички простор, о чему Вук у Предговору каже: „Ја сам провео године с Бошњацима и Ерцеговцима (из Пиве, из Дробњака, из Гацка, из Никшића), а провео сам године са Србијанцима од Лознице до Неготина; а провео сам године и по Њемачкој, од Земуна, па до Петриње. од Сентандреје, до Ршаве”, па је то уједно и речник општенационалног карактера.

${ }^{8}$ И: „Ако и нијесу у овој књизи скупљене све ријечи, али је постављен темељ да се скупе (колико је могуће у живом језику)" (Караџић 1818: VIII).

${ }^{9}$ Пре Вука систематског рада на бележењу лексике обредног карактера и описа самих обреда није било, иако је било полемичких и узгредних, свакако важних помена и описа из пера странаца, међу којима је посебно значајан Алберто Фортис (1774), и наших људи: Јеротеј Рачанин (1704), Antun Matija Relković (1776), Јован Рајић, Доситеј Обрадовић. Ђорђе Бранковић, Василије Бркић (1771), Петар Руњанин, Стеван Стратимировић, Сава Текелија (в. Филиповић 1972: 516-31). 
купација и један је од најважнијих задатака, што је резултирало етнографским и фолклорним материјалом, квантитетом и квалитетом код нас до тада непознатим.

Целокупна грађа Рјечника, као и обредна лексика, азбучно је устројена и протумачена немачким и латинским речима, при чему се аутор руководи општим поступком лематизације (основни облик, ознака рода, генитивни облик, понекад облици множине), додајући у неким случајевима и изведенице, као посебне речи, са или без објашњења.

Тако речи као: варин дан; женик, жеников, женити; заручница; испросиmи; јенђа; погреб, погребни; сунет, иако не садрже објашњења, својим основним значењем улазе обредно окружење. ${ }^{10}$ У Рјечнику се налазе и речи које, обрнуто, својим значењем не упућују на ритуал, али се у објашњењима с њиме повезују, на пример: језичан, спати, стратор, соколица, стреа, иуn - стиховима или другим фолклорним облицима, као илустрацијама, оне улазе у дати контекст. За илустрацију се издваја реч језичан, коју прати песмица: $О ј$ ти, зрно шенично / Ти не буди језично, / Па ћеш бити честито. / Ако л' будеш језично, / Нећеш бити честито, с објашњењем о ситуацији у којој се песма изводила: „пјевају ђевојци кад је убрађују". И, на крају, постоје речи из фонда обредне лексике које се не јављају као издвојене одреднице, већ само као саставни делови објашњења неке друге лексеме - на пример уз реч Божић се бележе: слама, жито, врећа, као обредни реквизити, а квоцање и пијукање као ритуалне редње. А све то је сведочанство о важности коју је Караџић придавао именовању и описима обредне праксе, односно народној култури свога времена.

Поступци семантизације у Рјечнику различите су природе и код обредне лексике, као и код осталих речи, иду од упућивања на другу реч, као - букара или ватриште; дружичало, ,, у Сријему говоре Ружичало, а у Банату побушени понедељак”; заветина, „носити крста, или крстоноше”; чеиз, ђевојачки дарови; рожсанство cf. Божић; четрдесетница, cf. даћа; гробница, рака; што су дублети (у случају регионализама), или синонимске речи. При томе, и само упућивање на другу реч може да садржи честицу обреда: као колалом лалом, „припјева се на бабинама”; част $\mathrm{cf}$. женидба; чауи, сf. женидба; или цветоносије (Ерц.) vide иъијети.

У објашњењима значења речи, као и обредне лексике, аутор користи и дескриптивни принцип семантизације (нпр: бадњак: „сирова церова главња, што се по обичају, уочи Божића ложи на ватру"; божји дан, први дан по Божићу; васиљиияа, „, колач што се по обичају мијеси на Мали Божић”; добјеглица (Ерц.) „ђевојка која добјегне (тј. сама дође за момка)”.

Сами обреди описују се у објашњењима речи, која се у целини или делом односе на одговарајућу праксу, као уз одредницу заветовати се, уз коју се део објашњења односи на заветовање појединца, а други на колективни завет, сеоску славу:

„У Србији свако село има један дан кога слави и светкује (и то обично бива љети, од Васкресенија до Петрови поста): скупе се сви сељаци (женско и мушко) на какво брдо, или на друго лијепо мјесто у селу; ту изведу своје пријатеље који им дођу из другије села, дозову попове и калуђере, те чате молитву, свештају масла и свете водицу, па се онда дигну сви с крстовима и иконама, по

\footnotetext{
${ }^{10}$ На важност Вукове лексике која није снабдевена опширним објашњењима за етнографска изучавања упутили су М. Филиповић 1972: 540541 и М. Радовановић 1973: 104.
} 
пољу (по житима и по ливадама), а ђешто и од куће до куће; потом дођу опет на оно мјесто, па онда ручају и читав се дан часте, играју и пјевају”,

што је евидентно преплитање прастарих веровања са елементима хришћанске праксе. И објашњења уз реч кум и прикумак, на пример, садрже описе два обреда, везана за крштено и венчано кумство, где се такође, посебно у опису стрижбе, преплићу стара веровања с хришћанским обредом. А и међусобна преклапања различитих празника и оказионалних ситуација с пратећим обредима, у оквиру једне речи у Рјечнику нису ретка и њима се, између осталог, указује на хибридност обредних ситуација и последично на поливалентност номинација. Иначе овде је у оба случаја реч о елементима живе обредне праксе у неким селима код Срба данас.

Караџић у објашњењима упућује и на одговарајуће наречје, бележећи дублете, везане за екавски и јекавски изговор: благовест (Рес. и Срем), vide благовијест; привенчати (Рес. и Срем), vide привјенчати; заветина (Рес. и Срем); vide завјетина. Уз исту реч он такође бележи податке о регионалној распрострањености: ,а у Јадру говоре: носити крста (крсте?), или крстоноше”. А уз реч дружичало: „у Сријему говоре ружичало, а у Банату побушени поднедељак. Исто тако, нпр: бабине (у Сријему ђекоји говоре бабиње); а за израз крсти куме дете „каже се у Сријему”. Тако је Вукова свест о потреби уочавања регионалних и дијалекатских разлика донела податке о географској разуђености обредне праксе у различитим местима и регијама и обогатила увиде у њу и, истовремено, отворила, усмерила и проширила могућности даљих истраживања, код нас и у словенском свету. ${ }^{11}$

А све то, прибегававање уобичајеном лексикографском поступку (основни облик, генитивни наставак и одређење рода), али и множина именице и изведене речи, као посебне одреднице, отежало је одређивање броја лексема у Рјечнику које се везују за обреде. Њихов број се релативизује и уврштавањем синонима, регионализама, али и међусобним преклапањем празника и пратећих обреда, описаних у оквиру једне речи. Стога се, заправо, може сачинити само груба процена броја ових појмова, односно ритуала који се у оквиру њих описују. Таквих речи - у којима се именује, наговештава, или мање више развијено описује обредно-обичајна пракса везана за животни циклус, породично-календарски празник славу, календарске промене у природи, као и обреде везане за обављање различитих послова - има око двеста.

Богатство обредне праксе у примарној лексици Рјечника очитује се посебно у описима благдана и светковина из годишњег циклуса, односно календарских прекретница за које се они везују, те послова и обредних радњи који се обављају у утврђене дане и њиховим делимично христијанозованизованим и христијанизованим празницима (Лазарева субота, Ђурђев дан, Ивањ дан, Јовањ дан, Петровдан...), чиме се уједно алудира на процес преплитања и наслојавања различитих представа у култури у освит 19. века, свакако и раније пошто оне не настају и не

\footnotetext{
${ }^{11}$ Тако су резултати Вукових истраживања у Рјечнику, па пример, због важности документације, инкорпорирани у и постали основа за неке од одредница у Речнику словенских старина (в. Плотникова 2015: 87).
} 
нестају умах. Лексеме из датог окружења у Рјечнику су најбројније и чине око половину речи од њиховог укупног броја. ${ }^{12}$

Зато, а и због немогућности да се у оквиру оваквог рада представи укупна лексика, за илустрацију Караџићевог поступка изабрана једна, цетрална реч из календарског циклуса, Божић, ${ }^{13}$ која се односи на почетак нове године, а која је уједно одредница с једним од најразвијенијих објашњења, и око које се у Рјечнику окупљају речи из аналогног значењског окружења. Тамо су јој придружене лексеме које су у вези с Божићем и празницима око њега: бадњак, бадњи дан (у објашњењу само превод), богојављенска водииа (само превод), богојављење (веровање и предање); божићни (само, ражањ, свијећа); божићовање (само превод); божићовати (само превод); Божји дан (само: „први дан по Божићу”); вара („Наврела вара од Дундулова дола (у приповијетки)"); варварица (само песмица); варин дан (само превод); вареник (садржи објашњење); варица (садржи објашњење); васиљииа („колач што се по обичају мијеси на Мали Божић”); коледа: колеђани, мали Божић, материце, милати, мирбожење (мирбожати се, мирбожити се); оци; печеница; положајник (све са објашњењима); рожанство (само в. Божић), сјакање (само сf. Божић), Тучин дан (само cf. печеница); чеснииа (с коментаром). Са или без објашњења, ове одреднице већ у Рјечнику 1818. обухватају најважније поступке, учеснике и реквизите везане за овај празник.

Уз реч Божић описују се различити обреди на Бадње вече као: уношење бадња$\kappa a$ и сламе, квоцање, певање - све су то радње које се, иначе, доводе у везу с плодношћу ([К]улишић 1998а: 50-52) и овај аграрни и хришћански празник уводе у дати контекст. Говори се о аналогним радњама на Божић, о јутарњем одласку на воду и посипању воде житом; о мешењу чеснице, пуцању из пушака, ујутро и пред ручак, молитви за софром, са свећама, и мирбожељу:

„Тј. изљубе се сви говорећи 'Мир Божји, Ристос се роди, поклањамо се Ристу и Ристову рожсанству'. Потом домаћин покупи оне свијеће у једну руковет и усади у жито, које стоји на софри у каквој карлици, или у чанку (свакојако жито помешано заједно; у том житу стоје и колачи којекакви), те онђе мало погоре, те и угасе оним житом. Оно жито дају жене послије кокошкама да носе јаја".

${ }^{12}$ То су речи: Аранђел, Бабини укови, батати, безимена неђеља, бијела неђеља, благовијест, богојављенска водииа, Богојављење, бадњак, бадњи дан, барјам, батати, богојављенска водииа, богојављење, Божић, божићни, божићовање, божићовати, Божји дан, букара, вара, варварица, вареник, варин дан, варица, васиљича, Васкрс, васкрсеније, васрсовање, васкрсовати, Великдан, велика неђеља, вељача, Видов дан, водичар, глува неђеља, дворкињ а, дода, додола, додоле, додолски, дружочало, дружичање, дружичати се, дуови, Ђурђев дан, Ђурђевски мјесеи, Ђурђии, заветина, завјетина, заветовати се, завјетовати се, Ивањдан, Јовањ дан, Јовањштак, коледа, колеђани, краљице, крстов дан, крстоноше, кумача, ладо, лазарева субота, лазарице, лазати, леља, литија, Мали Божић, материце, међуденвице, међудневички, месојеђе, мијена, милати, мирбожење, мирбожати се, мирбожити се, Митров дан, млада неђеља, младина, мученици, оци, Петров дан, печеница, покладе, покладовање, покалдовати, положајник, ранило, Рожанство, ружичало, себична недеља, сјакање, сјакнути, Спасов дан, спасовати, спасовиште, средопосни, сретеније, трапава недјеља, Трипуњдан, Тројице, Тројичин дан, Ускрс, ивије$m и$, чесница и сродне речи, као изведенице које овде нису набројане.

${ }^{13}$ Божић се помиње још у српским средњовековним споменицима, дубровачким изворима (према Бојанин 2005: 35, 73, 86-87, 89-92), као и под називом календе, или коледа, са конотацијама паганских светковина, такође од средњег века (Исто: 184, 189-195), што је иначе један и од назива за Божић. Али тако називају и поворке које су ишле о Божићу (в. Плотникова 2004: 81-84). А помињу га и српски писци у 18. веку: Д. Обрадовић и Ј. Рајић (в. Торњански Ркп. 2-4) 
Овим се успоставља веза између свега живог и неживог, људи и животиња, у кући, на њиви, у тору, што је обележје овог празника, који календарски сематизује почетак, и у опису се то истиче, односно имплицира. Следи опис ручка, односно божићне хране и пића, који према сведочењу из Рјечника имају карактеристике ритуалне гозбе. Каже се: „прије свега срчу вареник”, ломи се чесница. Даље се говори о прекомерној храни и пићу, на почеку овог периода, као и провоцирању ритуалног инцеста: „О Божићу се опити и побљувати није никакове срамоте (ако сам се опила, Божић ми је дошао, ако сам се открила, према свом ђеверу)”, што је обредно кодирано (в. Чајкановић 1994: 246-251), односно реч је о инверзији уобичајеног понашања које је карактеристика прастарих празника. Говори се и о томе да се ручак обавља на врећи, да се софра не диже и кућа не чисти три дана, што су даље типична обележја ове ритуалне праксе и уједно инверзије понашања у понаљању и нагомилавању аналогних радњи, које су у вези с култом мртвих и истовремено култовима везаним за плодност (в. Чајкановић 1994: 127-128). У овиру описа значења речи Божић и поступака и лица везаних за овај празник, помиње се положајник, за којег је у Рјечнику резервисана и посебна реч. А аутор се дотиче и сјакања и веровања да ће се жеље, у оквиру првог дана у години везаног и за соларни култ (в. Чајкановић 1994, 120-121), остварити: „На неким мјестима (као по Босни и Ерцеговини) сјачу на Божић: тј. домаћин рано ујутро виче: 'Сјај Боже и Божићу нашему (или нашој) по имену свим укућанима",. Као део описа овог обреда следи шаљива причица о томе како је Србин отишао бегу да моли жита за чесницу, а овај (сећајући се своје хришћанске прошлости?) тражио да му за узврат сјакне, што сељак и чини на смешан начин, доводећи у питање делетворност жеље, изречене за добробит неверника. Колико је овај комплексни опис обредно-обичајне праксе, с радњама, реквизитима, актерима, храном, пићем и вербалним исказима био Караџићу важан, казује чињеница да је готово у целини ушао у његову коначну верзију дескрипције Божића (Караџић 1867, према 1972: 155-156).

Исто тако, многи од поменутих обреда, актера и ритуалних предмета, у оквиру одреднице Божић, јављају се и као посебне речи; и уз њих такође допунска фолклорно-етнографска објашњења која употпуњују слику обредне праксе о Божићу у Караџићево доба, што уједно отвара могућности за даља испитивања.

Уз реч бадњак - чије је сечење, иначе, практиковано код јужних, али и осталих Словена (Толстој 1995б: 244-252), а у писаним изворима прати се од 13. века, у Дубровнику (в. Толстој 2001а: 14) - Караџић доноси објашњење значења речи. Описани су време и место сечења бадњачке гране; Рјечник помиње број бадњака, начине на који се уноси у кућу (домаћин, „или са воловима у Ерцеговини”); наводе се дијалози које укућани тада воде; говори о горењу и угарцима од бадњака и њиховој примени у воћњаку (да потпомогну плодност). А у оквиру поменуте речи упућује се и на реч cf. положајник. Положајник, каже се: „скреше бадњак, тј. узме ватраљ, па удара њиме у бадњаке ђе горе (да скачу варнице), говорећи: оволико говеда, оволико коња, оволико коза, оволико оваца...”, што употпуњује слику о радњама с њиме и такође пружа податке о првом посетиоцу и радњама за плодност, које су могуће у вези с теофанијом, односно с појавом бога даваца (в. Чајкановић 1994: 146-150), што је спорадично, као радња с измењеним значењима, одржано до данас. Положајник (први гост, првога дана у години који доноси берићет кући), иначе 
треба да буде неко за кога се сматра да је срећан, понекад се стога и бира неко ко је за ту прилику погодан. У вези с тим прастарим веровањем он, према опису из Pjeчника, посипа жито по кући, на разгрнути пепео меће паре, а жене га огрћу губером, „да им се вата дебео скоруп” - односно он обавља низ симболичких радњи везаних за плодност. А сви ови и аналогни поступци из култа плодности, које у вези с полазником описује Вук, потврђени су код нас и код других словенских народа (Усачова 1978: 27-47). И утолико је овај опис за разумевање укупне словенске традиције, везане за њега, драгоценији.

Уз реч чесница је објашњење о начину, времену, материјалу од којег се прави овај најзначајнији Божићни обредни хлеб код Срба ([К]улишић 1998в: 459-463; Плотникова 2001: 577-588); говори се о томе да је прави домаћин; о новчићу које се у њу ставља; о ломљењу чеснице и њеном дељењу међу укућанима. Све су то прастари обичаји из култа плодности, што показује и одредница милати се која се такође односи чесницу, за коју је у Рјечнику резервисана посебна реч, у чијем се објашњењу каже: „Приповједају да се Ерцеговци милају на Божић с чесницом, тј. узму двојица чесницу, па је окрећу међу собом и пита један другога: 'Милам ли се?' (тј. помила ли се иза чеснице). Онај му одговори: 'Милаш се мало.' А онај први онда рече: 'Сад мало а до године нимало.' (тј. да роди жито добро и да толика буде чесница да се нимало не помила иза ње). Радња се односи на ритуално скривање иза хлеба, које је посведочено у словенским културама (Толстой 1984: 5-72), а у новије време најпре код Вука, и то у развијеном облику и јасним функцијама. Међу обредним божићним хлебовима је и васиљица, за коју се у Рјечнику каже: „колач што се по обичају мијеси на Мали Божић” и још једном показује колико је мешење ритуалних хлебова у ово време било важно.

А и лексема вареник, с објашњењем: „вруће замеђено и забиберено вино, што се по обичају пије на Божић прије јела (у Сријему и у Бачк.)", иде у ред оних речи које, поред тога што се описују у оквиру речи Божић, имају посебну одредницу. И њен опис даље потврђује Караџићев однос према дијалекатској лексици и локалним обичајима. Пијење вареника пре јела је важно, јер поставља границу између поста и мрса, односно обележава почетак конзумирања алкохола и мрсне хране. Овај период, који се иначе се назива месојеђе и посведочен је још у 15 веку (Бојанин 2009: 107-116), Рјечник такође бележи говорећи о континутету сегментирања времена код Срба и Словена у дугом временском периоду. Лексема печенииа пак садржи детаљан опис, у којем се говори о врсти животиње која се једе за Божић; бележи се време убијања - туче се: „на Тучин дан”, с тим што се, без посебног објашњења, та одредница доноси у поменутом облику, али и као туцин дан. Затим се у одредници говори и о томе како и када се готови конзумира, што јасно указује на њен сакрални жртвени карактер (В. Чајкановић 1994: 137-146). А све упућује на Караџићево добро познавање појединих сегмената обредне праксе, везане за овај празник у њему савременом добу, које се практикује и данас..

За реч Божић везују се и речи: мирбожање, мрбожати се, варијантно мирбожити се, на коју упућује последња од њих, и у оквиру одреднице Божић њихово значење се, како је поменуто, и објашњава и значи мирење свих са свима, с јасно имплицираном семантиком о делотворности магије која се упражњава првога дана 
у години. Рожанство је пак такође посебна одредница, којом се само упућује на: cf. Божић, с асоцијацијом на рођење Бога.

Уз реч колеђани, стоји сf. коледа, и овде се односи на комплексну мушку опходну поворку и обреде за плодност код Словена, која се обављала на крају старе и почетком нове аграрне године (Кабакова 1999: 568-570; Виноградова 1999: 570-575), чији помен се прати у записма још од средњег века (Бојанин 2005: 192-196, 209, 220). У Рјечнику се за њих каже: „Приповиједају да су отприје ишла момчад уочи Божића од куће до куће, те играла и пјевала некакве пјесме од коледе, тј. готово уз сваку ријеч говорили су коледо! Ја се мало опомињем такове једне пјесме, како пјевају да им краве буду млијечне, да намузу пун кабао млијека, да окупају малога Бога: Да окупам, коледо!/ Малог Бога, коледо!/ И Божића, коледо" (у основи је преузето и 1867). Овим се сам обред везује за прошлост, иако се данас зна да су у Вуково време коледари ишли што, уосталом, потврђује и наведена песмица, чији садржај је такође везан за култ плодности и лустративне радње, што је у основи божићне народне обредности, о чему је Вук још на почетку свога рада много знао и у Рјечнику, у виду мозаика, оставио комплексна сведочанства.

У Рјечнику је вредно и објашњење уз реч батати, са стиховима који је тумаче и доводе у везу с актером божићног даривања и гласе: „Божић бата на обоја врата/ да унесе три товара злата ${ }^{14}$, који се, како аутор бележи, певају „у очи Божића”, јер они демистификују заблуду о Божић Бати, и даваоца правилно идентификују као Божића (малог бога), доносиоца богатства ${ }^{15}$, што је везано за прастаро веровање.

Посебну групу лексичких одредница чине: вара, варварища, вариияа, житно јело (панспермија), кувано на св. Варвару (4/17. 12), што је предбожићни обичај, такође из култа плодности ([К]улишић 1998б: 77-78), распрострањен пре свега код јужних, али и код осталих Словена (Толстој 2001б: 62-63). И док уз реч вара, стоји vide: варица, а за објашњење користи фраза: „наврела вара од Дундолова дола”, уз реч варварица каже се: „само у овој пјесми: „Варварица вари/ А Савица лади/ Николица куса" sf. варица. Реч пак у оквиру које се објашњавају цитирани стихови, који парафразирају време и начин справљања јела, а које се описује као: „жито што се по обичају кува на Варин дан: метне се у један лонац, или котао од свакога жита, или варива, те се скува заједно, па се једе други или трећи дан, пошто се олади; и зато се пјева" (поново се наводе исти стихови). Уз исту реч поновљен је и пословични израз из претходне, као алузија на потенцијални берићет у новој години, што је повезано с магијским радњама с варицом, које су у директној вези с поменутом фразом, у запису: „па се ујутру гледа с које је стране наврела, те на оној страни сију жита оне године, зашто кажу да ће онамо најбоље родити". Наведени опис се иначе налази у основи коначног Вуковог описа у Животу и обичајима (1867, према 1972: 153-154), и потоњих истраживања аналогних пракси код Словена (Толстој 1995в: 287-288)

Уз одредницу Богојављење (6/19. 1) - прастари словенски празник давања, који означава крај некрштених дана и нови почетак, а православни га славе као дан сећања на Христово крштење (в. Виноградова, Плотникова 1999: 667-672) - Ка-

\footnotetext{
${ }^{14}$ Варијанта ове песме публикована је у целини 1841: бр. 194.

${ }^{15} \mathrm{O}$ томе и М. Шипка, Зашто се каже Божић-Бата, https://www.sedmica.me/zasto-se-kaze-bozicbata/, преузето 8.1. 2018.
} 
раџић доноси, иначе распрострањено, прастаро веровање да се на овај дан отвара небо, односно да је тада могуће успоставити контакт с Богом даваоцем, који испуњава жеље. А у вези с тим је и пратеће шаљиво предање. У њему се говори о човеку који је, полакомивши се на благо и, промоливши главу кроз прозор кад се небо отворило, грешком рекао: „Дај ми Боже од осмак главу”, уместо: „Дај ми, Боже, осмак блага". А кад му је Бог испунио ову жељу, није могао да је врати, па је био приморан да на то потроши две преостале жеље - и тако остао без ичега. Уз исту реч описан је и распрострањени обичај купања у хладној води, који се у бележењима код Руса прати још од 17. века, ${ }^{16}$ а одржао се до наших дана и у вези је с веровањем у посвећеност воде, крштењем, тренутком који затвара циклус Божићних празника.

Број одредница Рјечника (1818), везаних за обредну лексику и календарске промене у природи, посебно божићне празнике и њихова објашњења (што је овом приликом показано) - у које су укључене различите представе, веровања и фолклорни облици, повезани с обредном праксом - заправо фокусирање на међуоднос речи и културе, језика и културе савременог доба, резултирало је етнографским и фолклорним материјалом, квантитетом и квалитетом код нас до тада непознатим. Рјечник је стога документ прве врсте о времену и средини у којој је аутор живео. Али будући да су обреди капсуле у којима се чувају прастари остаци живота, он је и сведочанство о начину живота и веровањима много пре тога, и то не само код Срба већ и Словена уопште. Ово потврђује аналогна грађа код осталих словенских народа, те утицај који је Караџић имао на друге словенске речнике са етнографском грађом у прошлости (Радовановић 1973: 74-75), а у наше време речника „Словенске старине” (в. Плотникова 2015: 85-97), да само наговестим путеве којима би се даља истраживања могла кретати.

\section{Литература}

Бојанин С. „Меснице - средњовековни назив за зимски мрсни циклус.” Гласник Етнографског института САНУ, LVI, I/1 (2009): стр. 107-116.

Бојанин С. Забаве и светковине у средюовековној Србији. Београд: Историјски институт, 2005.

Виноградова, Л. Н. „Колядование.” Толстой Н. И. (ред.). Славянские древности. Этнолинвистический словарь (в пяти томах). Том II. Москва: Российская академия наук - Институт славяноведения, 1999: стр. 570-575.

Виноградова Л. Н., Плотникова Л. А. „КреЩение (Богоявление).” Толстой Н. И. (ред.). Славянские древности. Этнолинвистический словарь (в пяти томах). Том II. Москва: Российская академия наук - Институт славяноведения, 1999: $667-672$.

Добрашиновић Г. (прир.) Преписка I. Сабрана дела Вука Караџића ХХ. Београд: Просвета, 1988.

\footnotetext{
16 Чак се у реци Москви купао цар са велможама (Виноградова, Плотникова 1999: 670)
} 
Ивић П. (ур.). Српски рјечник (1818). Сабрана дела Вука Караџића. Београд: Просвета, 1966.

Кабакова Г. И. „Коляда.” Толстой Н. И. (ред.). Славянские древности. Этнолинвистический словарь (в пяти томах). Том II. Москва: Российская академия наук - Институт славяноведения, 1999: 568-570.

Караџић В. С. Мала простонародња славено-сербска пјеснарица. Сабрана дела Вука Караџића. Књ. прва. Приредио В. Недић В. Београд: Просвета, 1965.

Караџић В. С. Српски рјечник истолкован њемачким и латинским рјечима. Сабрана дела Вука Караџића. Књ. прва. Приредио П. Ивић. Београд: Просвета, 1966.

Караџић В. С. „Живот и обичаји народа српскога.” Филиповић М. (ур.). Сабрана дела. Књ. 17. Београд: Просвета, 1972.

[К]улишић Ш. „Божићна слама.” Кулишић Ш., Петровић П., Пантелић Н. (ур.). Срnски митолошки речник. Београд: Етнографски институт САНУ - Интерпринт, 1998а: стр. 50-52.

[К]улишић Ш. „Варица.” Кулишић Ш., Петровић П., Пантелић Н. (ур.). Српски митолошки речник. Београд: Етнографски институт САНУ - Интерпринт, 1998б: стр. 77-78.

[Кулишић] Ш. „Чесница.” Кулишић Ш., Петровић П., Пантелић Н. (ур.). Српски митолошки речник. Београд: Етнографски институт САНУ - Интерпринт, 1998в: стр. 459-463.

Плотникова А. А. Словари и народная культура. Москва: РАН, 2000.

Плотникова А. А. Этнолингвистическая география Южной Славии. Москва: Индрик, 2004.

Плотникова А. А. „Српска грађа у московском речнику словенске старине.” Ђорђевић С. Љајић Д. и др. (ур.). Савремена српска фолклористика II. Београд: Удружење фолклориста Србије, 2015: 85-97.

Радовановић М. Вук Стефановић Караиић етнограф и фолклорист. Београд: Српска академија наука и уметности, 1973.

Стојановић Љ. Живот и рад Вука Стеф. Караиића. Београд: Штампарија „Макарије", 1924.

Толстој С. Љубинковић Р. (ред.). „Чесница.” Словенска митологија. Београд: Zepter Book World, 2001: стр. 577-588.

Толстой Н. И: „Фрагмент славянского язычества: архаический ритуал-дијалог.” СБФ. Москва, 1984: стр. 5-72.

Толстой Н. И. Язык и народная культура: очерки по славянской мифологии и этнолингвистике. Москва: Индрик, 1995а. 
Толстој Н. И. „Балканскословенски обреди: структура и географија, Бадњак.” Језик словенске културе. Ниш: Просвета, 1995б: стр. 244-248.

Толстой Н. И. „Варвара.” Толстой Н. И. (ред.). Славянские древности. Этнолинвистический словарь (в пяти томах). Том I. Москва: Российская академия наук - Институт славяноведения, 1995в: 286-291.

Толстој Н. И. „Бадњак.” Толстој С., Љубинковић Р. (ред.) Словенска митологија. Београд: Zepter Book World, 2001a: стр. 14.

Толстој Н. И. „, Варвара.” Толстој С., Љубинковић Р. (ред.) Словенска митологија. Београд: Zepter Book World, 2001б: стр. 62-63.

Торњански С. „Коледарске и божићне песме у контексту зимских календарских обреда.” Ркп. докторске дисертације: стр. 2-4.

Усачова. „Обряд 'полазник' и его фольклорные элементы в ареале сербскохорватского языка.” СБФ. Москва, 1978: 27-47.

Филиповић М. (ур.). „Вук Караџић и српска етнологија.” Сабрана дела Вука Каpaиића. Књ. 17. Београд: Просвета, 1972.

Чајкановић В. Студије из српске религије и фолклора 1910-1924. Пр. В. Ђурић. Београд: СКЗ - БИГЗ - Просвета - Партенон М. А. М., 1994.

Зоя С. Каранович

ОБРЯДОВАЯ ЛЕКСИКА И ОБРЯДЫ В «СЛОВАРЕ» (1818) ВУКА СТЕФАНОВИЧА КАРАДЖИЧА

Резюме

Предметом данного исследования является обрядовая лексика в Словаре (1818) Вука Стефановича Караджича, принципы номинации обрядовых актов и дескрипция обрядовой традиционной практики, которая, судя по объему словника и разнообразию статей, в нем представленных, была частью праздничной жизни времен Вука, и автор проявлял к ней большой интерес. Богатство описаний проявляется в толковании значения частично христианизованных праздников из календарного цикла и связанных с ними аграрных праздников, а также в описаниях верований, актов, участников, атрибутов и вербализации, которая упомянутые праздники сопровождала, - стихах, истории, фразеологии. Богатство информации, а также лексики с символическим значением в стихотворных и прозаических формах находится в Словаре и в описании обрядов перехода - рождения, брака, смерти, а также семейно-календарного праздника Славы. А поскольку все слова в Словаре, которых множество, невозможно детально проанализировать, в данной работе отдельно представлена лексема Божић (Рождество) и слова, которые относятся к описанию принадлежащих к этой сфере ритуалов, которых в Словаре более тридцати. Все это один из показателей того, какое важное место занимала традиционная обрядовая практика в духовной культуре сербов времен Вука Караджича, но и шире, в других славянских общинах, в которых зафиксирована аналогичная традиционная обрядовая практика. Перечислена, однако, только часть лексики в Словаре (1818), составление которого ввело Вука Караджича в ряды пионеров сербской фольклористики и этнографии.

Ключевые слова: Вук Караджич, Словарь 1818, обрядовая лексика, обряды, сербская культура, славянские культуры. 